In: J. Mienert, Weaver, P.P. (Editor), European Margin Sediment Dynamics : Side -Scan Sonar and Seismic Images. Springer, Berlin, pp. 233-238.

\title{
The Celtic deep-sea fan: seismic facies, architecture and stratigraphy
}

\author{
L. DROZ ${ }^{1}$, G. A. AUFFRET ${ }^{2}$ AND B. SAVOYE ${ }^{2}$ \\ ${ }^{1}$ Institut Universitaire Européen de la Mer, UMR 6538, Plouzané, France. \\ ${ }^{2}$ IFREMER, DRO/GM, Laboratoire Environnements Sédimentaires, Plouzané, France.
}

The Celtic Fan (Evans 1996; Droz et al. 1999; Auffret et al. 2000) is a radial turbidite accumulation at the mouth of the two main systems of canyons of the Celtic margin: the Whittard System to the west and the Shamrock System to the east (Fig. 1).

Tentative correlations between SEDIFAN seismic profiles and site 400 of DSDP Leg 48 (Montadert and Roberts 1979; Fig. 1) indicate that the sedimentary section is divided into preand post-Eocene series (SI and SII, Fig. 2) by a major regional erosional unconformity (H3). $\mathrm{H} 3$ is correlated to the Upper Eocene-Lower Oligocene hiatus related to the end of compressive Pyrenean deformations in Upper Eocene times. This hiatus also correlates with the Oligocene worldwide lowering of sea level and the Oligocene inversion of the continental shelf (Ziegler 1987).

Post-Eocene series include a lower seismic unit (unit IIA) topped by an angular unconformity $(\mathrm{H} 4)$ where fan deposits are on- or downlapping. $\mathrm{H} 4$ is correlated to the intra-Lower Miocene hiatus of DSDP site 400, indicating that turbidite deposition on the Celtic margin began in early to middle Miocene times.

Fan sediments are organised in three main turbidite units (IIB2, IIC and IID), separated by minor angular, locally erosional unconformities ( $\mathrm{H} 5$ and $\mathrm{H} 6)$. These horizons are correlated respectively to the Miocene/Pliocene and late Pliocene-early Pleistocene tectonic events (Ziegler 1987; Evans 1990) associated with periods of relative sea level lowering. Very high resolution PASISAR data (Fig. 3) revealed that the lower units include numerous small, frequently shifting channel/levée systems, probably of high sand content, that progressively prograded basinward. A smaller number of channel/levée systems, higher levées and more permanent channels in the youngest unit (IID) are probably related to lower sand content and seem to indicate an abrupt change of sedimentation conditions during the Pleistocene.

These modifications of the sedimentary regime reflect changes that could be related to a shift of feeding sources, from the "Fleuve Manche" (Lericolais 1997) to the Irish Sea (Fig. 4), in connection with the uplift of the continental shelf and the development of the ice-sheet on the British Isles in Early Quaternary times.

\section{Acknowledgements}

We thank the officers, crew members and techicians of the RV l'Atalante and Le Suroit, on board which were collected the seismic data shown in this paper. 


\section{References}

Auffret GA, Zaragosi S, Voisset M, Droz L, Loubrieu B, Pelleau P, Savoye B, Bourillet JF, Baltzer A, Bourquin S, Dennielou B, Coutelle A, Weber N, Floch G (2000) Premières observations sur la morphologie et les processus sédimentaires récents de l'Eventail celtique. Oceanologica Acta 23 (1):109-116.

Droz L, Affret GA, Savoye B, Bourillet JF (1999) L'éventail profond de la marge celtique: stratigraphie et évolution sédimentaire. Comptes Rendus de l'Académie des Sciences, Paris, Sciences de la terre et des planètes 328: 173-180.

Evans CDR (1990) United Kingdom offshore regional report: the geology of the western English Channel and its western approaches. London: HMSO for the British Geological Survey, 93pp.

Evans D (1996) Physiography, pathways and processes on the European continental margin (1:5 000 000, Mercator projection). British Geological Survey, editor.

Lericolais G (1997) Evolution plio-quaternaire du Fleuve Manche: stratigraphie et géomorphologie d'une plateforme continentale en régime périglaciaire. Thèse de l'Université de Bordeaux I, 265pp.

Montadert L, Roerts DG (1979) Initial Reports of the Deep Sea Drilling Project, volume 48. U.S. Government Printing Office, Washington.

Ziegler PA (1987) Celtic Sea-Western Approaches area: an overview. Tectonophysics 137: 389-420. 